\title{
Eco Meluha: An Ecocritical Reading of Amish Tripathi's The Immortals of Meluha
}

\author{
Abel Justine \\ Post Graduate \\ St. Joseph's College (Autonomous) \\ Devagiri Calicut(Kozhikode), Kerala, India \\ abeljustine465@gmail.com
}

Abstract

The term 'ecocriticism' was coined by William Rueckert in 1978 and it was popularized by Cheryll Glotfelty through her 1996 work The Ecocriticism Reader. According to her, ecocriticism is the study of the relationship between literature and nature or the physical environment. Ecocriticism later turned out to be a pivotal area in literary theory. The theory posits that human beings are inherently related to nature. They are dependent on nature in one way or another. For example, air, water, food etc. are inevitable aspects for man. In the same way, nature too is dependent on man.

Keywords: Ecocriticism, Fiction, Nature, Culture

Ecocriticism takes on a different platform to analyze connections between man and nature often on a symbolic realm. It explores environmental issues on a literal as well as a metaphorical level. The issues here do not simply get limited to the ways in which man destroys nature. It highlights even the literary devices that are used in a text in a particular way in order to create a link between the plot and the natural environment on another dimension.

The Immortals of Meluha published in 2010 is the first book of a trilogy written by the Indian English author Amish Tripathi. It is exclusively a book on the Hindu God Shiva. 
Tripathi creates an earthly setting and brings the character of Shiva as to be a human, following the myth in a radical and postmodern way.

Meluha is an age old yet magnificent empire which was once built by Lord Ram. Daksha, who is the present king of the empire invites the local tribes to his palace and henceforth comes Shiva and his Guna tribe. Later, Ayurvati, the chief of medicine of the Meluhans notices the blue throat of Shiva and gets bewildered on witnessing the mighty Lord. The Meluhans hail him as the Neelkanth who is now born again to save them. Shiva gets to know about the conflict between the Meluhans and the Chandravanshis. He goes to Mount Mandar from where he learns about the reason for his blue throat. He later declares war against the Chandravanshis. A ferocious battle takes place with the Meluhans emerging victorious.

The novel is not set in some ancient European locale but in a different world with distinct customs of beliefs. The story is undoubtedly derived from myths and an interesting aspect of the text is the intermixing of science and myth within the narrative. India is a land of multiculturalism and different conventions and traditions. Even in oriental studies, the west is seen as cultured and the east very much indebted to nature. Tripathi incorporates his so called 'Indianness' into his book. And this is what makes it a specimen for an ecocritical reading.

In all the chapters of the book, the reference to nature seems inevitable. Shiva and his tribe are the people with utmost importance from the beginning of the work. It is clearly established that he and his Guna tribe are among those who are yet to be civilized in B. C. 1900. The Meluhans on the other hand are quite advanced in almost every aspect compared to the other cultures. Be it medicine, technology, transportation or anything. They are more cultured. Even the structure of their palace is symbolic of their so called sophistication. The author describes their land as having everything constructed by man and there is almost 
nothing that exists as natural. Their towers, walls, beds and so on are crafted by the hands of men. What Tripathi does here in the first few chapters is in fact a contrast between the Guna tribe of Shiva and Meluha. The Meluhans do admire Shiva and they promote medicines taken from the secrets of nature; but still, the tribe of the divine- Shiva are the stewards of nature which makes them the real masters of the earth.

There are several instances in the story in which Shiva intakes marijuana. This is again in fact drawn from the myth of Shiva using weed but here in the novel, it kind of reinforces the idea of the oneness of man with nature. Shiva tells that marijuana calms and clears his mind. He uses this product of nature to relax in between all the confusion he faces in Meluha. The theory thus takes a leap from simply an ecocritical to an ecopsychological level.

When the Pandit asks Shiva about his belief in Gods, he replies, "I believe that the real God exists all around us. In the flow of the river, in the rustle of the trees, in the whisper of the winds. He speaks to us all the time."(Tripathi 46) Shiva undeniably pledges his allegiance to the real God which he believes to be the nature itself.

Shiva finds difficulty in sleeping on a bed made of cotton when he is in the palace. It is entirely a new experience to him. He tries different positions but none helps. Finally he gets off, lays the sheet on the floor and lies down there to his satisfaction. He always slept on the floor. The fluffy bed made him excited in the beginning but later turned out to be discomforting and irksome which turns light into the symbolic understanding of all cultured societies.

On seeing the bricks that are to be used for construction, Shiva asks Nandi whether they were made as per some standard process. When Nandi affirmed so and asked him how did he know, Shiva replies, "They are all exactly the same dimension."(Tripathi 61)This instance posits the difference in the ideology between nature and culture. There is inherent 
harmony in nature. One needn't create them. As Shiva tells the Pandit earlier in the text that all we have to do is listen to nature, the protagonist puts forth the idea about the innate essence of peace and balance in nature. But when it comes to culture, man is always desperate in trying to bring balance to the world, which is subtly shown in the idea of crafting the bricks that are a product of nature, in exactly the same dimension.

Alison Byerly stated, "The aesthetic view of the wilderness that is part of the picturesque legacy has had a crucial effect on public land management politics. It has taught us to value nature, but the criterion for evaluation is the quality of aesthetic experience a landscape provides.”(Byerly 53)Culture always defined nature in terms of wilderness. When it comes to the idea of preservation, they hide their hypocrisy by inclining to the physical beauty of nature, not what is truly natural and native to an ecosystem.

The Immortals of Meluha not only presents a spectacle of nature but an aesthetic milieu which calls for the significance of the relationship of man towards the same. One can say the work is kind of a façade that house a general tendency to celebrate nature on its physicality but in fact it is critical about the modern cultural thinking about nature.

Tripathi in his book is not constructing a fetishist picture of nature. He is not stressing of the concept of nature being associated with wilderness and savagery. He is not delineating nature to a realm of no scientific and intellectual progress. What he mainly does is reminding the path of man towards culture. It was from nature that men learned. The author calls for a reformation. Despite using nature for anthropocentric purposes, he stresses on the need for man to understand the relevance of nature, how pivotal a role nature had and still has on an individual's life and existence. This relationship is not just limited to the physical dimension but also a larger symbolic dimension. Every man must consider nature in the way Shiva did, embrace it as it isn't bound to material ingredients but also affects the psychological consciousness of all people. 


\section{Works Cited}

Byerly, Alison. "The Uses of Landscape: The Picturesque Aesthetic and the National

Park System." In C. Glotfelty and H. Fromm (Eds.), The Ecocriticism Reader: Landmarks in Literary Ecology (pp. 52-68). Athens, Georgia Press, 1996.

Tripathi, Amish. The Immortals of Meluha. Chennai, Westland, 2010. 